\title{
Hajnal Zsolt*: A fogyasztói szerződések joga az Európai Unió jogában: közös alapok
}

\author{
Debreceni Jogi Mühely, 2014. évi (XI. évfolyam) 1-2. szám (2014. június 30.)
}

\section{Bevezetés}

Az utóbbi évtized fogyasztóvédelmi jogalkotása egyértelmủen felmutat egy olyan tendenciát, hogy a szerteágazó - a szabályozás célját tekintve ugyanakkor homogén - fogyasztóvédelmi jogszabályok közös alapjait felmutatva új horizontális keretrendszereket teremtsen, vagy a már meglévő jogszabályokat a közös standardok menték újragondolja. Az európai fogyasztóvédelmi joganyag rendszerezése és áttekintése különösen akkor vált fontossá, amikor a Common Frame of References (Közös Referenciakerete, továbbiakban CFR) program kezdetét vette, majd egy horizontális jogintézmény (Consumer Rights Directive, fogyasztói jogokról szóló irányelv, továbbiakban CRD) megalkotásának munkálatai elkezdődtek[1]. Az európai fogyasztóvédelmi szabályozás közös standardjainak keresése a hatályos jog különböző szempontok szerinti rendszerezését, és áttekintését szükségelteti, amely nem egyszerü feladat. Az európai fogyasztóvédelmi jogalkotás eredményeit első megközelítésben a fogyasztó alapvető jogai szerint csoportosíthatjuk. A rendszerezés feladatát ugyanakkor a fogyasztóvédelmi joganyag áttekintése során elvégezték, így hagyatkoznék a már felállított és általam is követhetőnek gondolt kategóriákra és besorolásokra. A SchulteNölke/Twigg-Flesner/Ebers[2] által elvégzett fogyasztóvédelmi joganyag analízisébe vont rendszertani következtetéseket analóg formában felhasználva (a következtetések egy lehetséges horizontális jogintézmény felépítésére tettek volna javaslatot, mindamellett, hogy a hatályos fogyasztói szerződések jogának közös standardjait, alapintézményeit vetették össze egymással és a nemzeti szabályozással) alapelvi szinten próbálok közös jellemzőket felkutatni, és ezáltal próbálok a fogyasztói szerződések jogáról egységes képet nyújtani.

\section{A fogyasztók magánjogi védelmének jogtechnikai modelljei}

Abban a kérdésben, hogy a fogyasztót milyen körben és milyen intenzitással kell védeni, megoszlanak a vélemények. A vita hátterében a piacgazdaságot müködtető szerződési szabadság és magánautonómia polgári jogi alapelve áll. A felek szerződési szabadsága a jóhiszemü joggyakorlást szem előtt tartva lehetővé teszi, hogy szabadon rendelkezzenek egymás közötti szerződéses viszonyaikban céljaik elérése érdekében, amelyekbe az állam nem, vagy csak korlátozott és indokolt mértékben avatkozhat bele. Ugyanakkor a szerződési szabadság korlátlan érvényesülése piacgazdasági viszonyok között alkalmas a gyengébb fél érdekeinek csorbítására, a magánjogi viszonyokat egyébként jellemző mellérendeltség eltolására (ennek klasszikus megjelenési példái az általános szerződési feltételek). , illetve Hogyan részesíthetjük védelemben a fogyasztói érdekeket a jogi szabályozás eszközeivel? A kérdésre adandó részletes válasz előtt a szabályozástechnikai megoldásokat rendszerezem: a fogyasztókat védö jogintézményeket - Lurger/Augenhofer vélekedését osztva - alapvetően két csoportba sorolhatjuk a szabályozási modell tekintetében: a tájékoztatási modellbe és a szociális modellbe. Az információs, tájékoztatási modellbe soroljuk a fogyasztókat védő többlet-tájékoztatási kötelezettségeket, míg a szociális modell lényege a szerződéses jogviszonyba történő beavatkozás, például a tisztességtelen szerződési feltételhez füzött semmisség révén. A fogyasztó elállási joga a két modell között félúton, talán a szociális modellhez valamivel közelebb helyezkedik el.

Az információs modell: a liberális közgazdaság tudomány művelői számára a szerződési szabadság elve lehet az egyedüli uralkodó elv a szabályozás kialakításakor, így a gyengébb fél érdekében alkotott védelmi intézkedések a lehető legkevesebb mértékben avatkozhatnak bele a szerződéses jogviszonyba. A modell elvi alapjául szolgál, hogy a gazdálkodó és a fogyasztó 
közötti egyensúly-eltolódásos helyzet egy „információs csapdán” is alapul, tehát a fogyasztó legtöbbször nem rendelkezik azokkal az ismeretekkel, amelyek birtokában megalapozott és tudatos vásárlási (szerződéskötési) döntést hozhat. Emiatt a gazdálkodó meghatározott többletinformációkat köteles a fogyasztónak átadni, amelyeket értékelve, összehasonlítva, feldolgozva ésszerü döntést hozhat a fogyasztó. Az információs modell dogmatikai megalapozása az EuB több ítéletében is testet öltött, miszerint a fogyasztóvédelmi szabályok alkalmazásakor egy ésszerü és tudatos fogyasztótól elvárható magatartást kell alapul venni, méghozzá olyan fogyasztóét, akinek joga van a tájékoztatáshoz, és a kapott információkat megfelelöen értékelni is tudja.[3]

A szociális modell alapjául az a megfontolás szolgál, hogy a tájékoztatási garanciák önmagukban nem elégségesek a fogyasztók védelméhez. Az elállási jogok, a szerződést semmisséggel szankcionáló jogkövetkezmények a tájékoztatási modellel ellentétben már egy létrejött szerződéses jogviszonyba avatkoznak be. A tájékoztatási többletjogok sok esetben nem teszik lehetővé, hogy a fogyasztó egy-egy szerződéskötési szituációban helyes döntést hozhasson, éppen a szituáció szokásostól eltérő volta, vagy a szorongatott helyzet miatt képtelen az információk feldolgozására. Annak meghatározására, hogy a védelem határait hol húzzuk meg, a fogyasztói minta kialakítása nyújt segítséget. A fogyasztói modell vagy minta mind az információs, mind pedig a szociális modell védelmi szintjének meghatározásánál szerepet játszik, ugyanis a mintául szolgáló fogyasztó értelmi, szellemi képességeihez igazítják a beavatkozás mértékét és a védelem szintjét. Értelemszerüen egy ügyvéd nem igényli a védelem olyan magas szintjét, mint egy föiskolai hallgató, ugyanakkor a jogalkotó általánosítani köteles, és csak különös méltánylást érdemlő esetekben határozhatja meg a védelem szintjét ettől eltérően (fiatal- és gyermekkorúak védelme). Ennek megfelelően azon fogyasztói magatartások, amelyek elérik vagy meghaladják a jogi szabályozás által követett fogyasztói modell szintjét, védelemben részesülnek, míg azok, amelyek ez alatt maradnak, kiesnek a védelemből.

\section{A fogyasztóvédelmi szabályozás által érintett alanyi kör \\ 3.1. A fogyasztó európai fogalma}

Az európai jogalkotás és jogalkalmazás rendkívül sokoldalú és effektív hatás gyakorol a tagállami magánjogokra. Ezen belül is különösen igaz ez a fogyasztóvédelmi magánjog alakulására. Az utazási szerződésekről szóló, valamint a korábbi timeshare irányelv kivételével az európai irányelvek a természetes személyek meghatározott körére szükítik a fogyasztó fogalmát. E felfogás mellett konzekvensen kitart az $\mathrm{EuB}$ is, amikor joggyakorlatában a nem természetes személyeket kizárja a fogyasztó fogalmából, valamint az átlag/minta fogyasztót, mint szubjektumot górcső alá helyező, döntéseiben testet öltő impulzusaival arra készteti és kényszeríti az európai jogalkotókat, hogy finomabbra hangolják az európai mintafogyasztóhoz igazított védelmi szintet.[4] A fogyasztóvédelmi irányelvek hasonló fogyasztó fogalmakat használnak, jóllehet az általuk szabályozott eltérő szituációs környezet a használt fogalmak tekintetében is különbségeket eredményezhet, így teljesen egységes európai fogyasztó fogalomról nem beszélhetünk. A fogyasztónak a leggyakoribb megfogalmazás alapján azokat a természetes személyeket tekinthetjük, akik szakmai, üzleti tevékenységükön vagy foglalkozásukon kívül eső célból járnak el.[5] Egy teljesen eltérő meghatározást tartalmaz a szervezett utazási formákról szóló 90/314/EGK tanácsi irányelv,[6] amely a fogyasztót „személyként” jelöli meg, lehetővé téve a jogi személy fogyasztóként történő minösítését. Ezen kívül a szerződéses viszonyban betöltött szerepek szerint is fogyasztói minősítést nyer nemcsak a közvetlenül szerződést kötő fél (megbízó fél), hanem a kedvezményezett, illetve az engedményes. A szerződéses kötelezettségekre alkalmazandó jogról szóló, Rómában 1980. június 19-én aláírt nemzetközi egyezmény 
kihirdetéséről szóló 2006. évi XXVIII. törvény is olyan szerződést definiált fogyasztói szerződésként, amelynek „tárgya áruk szállítása vagy szolgáltatások nyújtása egy személy (,a fogyasztó") részére, annak szakmai vagy üzleti tevékenységén kívüli célra, továbbá azon szerződéseket, amelyek az ilyen ügyletek finanszírozására irányulnak.[7] Az ezt felváltó Európai Parlament és a Tanács 2008. június 17-i 593/2008/EK rendelete a szerződéses kötelezettségekre alkalmazandó jogról (továbbiakban Róma I.) fogyasztói szerződésként már olyan szerződést nevesít, amelyet „egy 'természetes személy' üzleti vagy szakmai tevékenységén kívüli célra köt [...].” A Tanács 44/2001/EK számú a polgári és kereskedelmi ügyekben a joghatóságról, valamint a határozatok elismeréséröl és végrehajtásáról szóló rendelete a fogyasztót szintén személyként definiálja.[8] Az eltérő szabályozás indokául pontosan az szolgálhatott, hogy a Brüsszel I. rendelet a Római Egyezmény eljárási jogi párját alkotta, így elsősorban ahhoz kellett igazodnia, valamint a sok esetben kiterjesztő tagállami szabályozásokhoz. A minimum harmonizációs alapelv útján a tagállamok a fogyasztó fogalmát eltérően szabályozták, sok esetben más személycsoportokra is kiterjesztve a fogyasztóvédelmi szabályozás személyi hatályát, ami az európai fogyasztó fogalmának kialakulására is hatást fejtett ki az EuB gyakorlatán keresztül.

Leszükithetö-e a fogyasztó fogalma a természetes személyekre?

A legtöbb irányelv a fogyasztók védelmét a természetes személyekre szükíti. Egy sor tagállam követte ezt a szabályozást, azonban néhányan nem éltek ezzel a korlátozással. A fogyasztó fogalmának természetes személyekre történő leszükítése kizárja annak lehetőségét, hogy fogyasztónak tekintsük azt a jogi személyt, amely nem szakmai vagy üzleti tevékenysége körébe eső céllal köti a szerződést, valamint az olyan jogi személyeket,- mint sportegyesületek, alapítványok, társasházak - amelyek jellegüknél és tevékenységüknél fogva részesülhetnének a fogyasztókat megillető védelemben.

Az EuB egy 2001-ből származó ítéletében már vizsgálta azt a kérdést, hogy jogi személy minősülhet-e fogyasztónak. A Cape Snc v. Idealservice Srl és Idealservice MN RE Sas v. OMAI Srl ügyek[9] tényállása szerint a Cape Snc szerződést kötött az Idealservice-szel, amelynek alapján I. italautomatákat szállított C.-nek. Az automatákat C. saját helyiségeiben tárolta, és személyzetének biztosította. A későbbi jogvita kialakulásakor C. a fogyasztókkal kötött szerződésekben alkalmazott tisztességtelen feltételekről szóló 93/13/EGK tanácsi irányelvre hivatkozott, fogyasztónak minősítve magát a szerződéses viszonyban. Az EuB elözetes döntéshozatali eljárás körében az irányelv személyi hatályát értelmezte, és arra kérdésre, hogy az irányelv értelmében fennáll-e a szóban forgó jogvitában a jogi személy fogyasztói minősége, egyértelmüen úgy foglalt állást hogy az irányelv hatálya természetes személy fogyasztókra terjed ki.

Kisvállalkozások fogyasztói minőségének problematikája

A kezdeti tagállami joggyakorlat több esetben követte azt a célt, hogy a kisvállalkozásoknak is biztosítani kell a fogyasztókat megillető védelmet egyedi esetekben, amikor nem szakmai vagy üzleti tevékenységük körébe eső célból járnak el. Az a felfogás képezte a joggyakorlat alapját, amely szerint a gazdálkodók ilyen esetekben nem tudnak magas fokú szakmai tudást felmutatni, valamint nem üzleti tevékenységi körükben végzik a szolgáltatást, így a laikus félhez hasonló tulajdonságokkal rendelkeznek a szerződéses viszonyban. Az EuB a di Pinto ügyben[10] foglalkozott a kisvállalkozás, valamint az üzleti tevékenység befejezéséhez kapcsolódó fogyasztói minőség megítélésével. Az eset tényállása szerint az alperes a SARL „Groupement de l' immobilier et du fonds de commerce” társaság volt, amely egy periodikus, vállalkozások eladási ajánlatait hirdető újságot jelentetett meg. Egy ilyen hirdetés feladásánál az előzetes érdeklődést követően az alperes képviselői személyesen keresték fel lakásában vagy munkahelyén a hirdetést feladó üzlettulajdonost, ahol a szerződés is megkötésre került. Ezzel kapcsolatban az a kérdés merült fel, hogy az a vállalkozás, amely egy ilyen szerződést 
kötött az alperessel, részesül- e az üzlethelyiségen kívül kötött szerződések esetén a fogyasztók védelméről szóló tanácsi irányelv védelmében. Az EuB egyértelmüen kimondta, hogy egy olyan gazdálkodó, aki hirdetési szerződés keretében a vállalkozását kívánja értékesíteni, nem minősül az irányelv értelmében fogyasztónak. Az EuB indoklásában kitért arra, hogy a szerződés megkötése, valamint a szakmai és az üzleti tevékenységi kör viszonyát is vizsgálni kell. A gazdasági tevékenység megszüntetése érdekében tett előkészítő lépések kifejezetten üzletvezetési tevékenységnek minősülnek, és nem a személyes vagy családi szükségletek kielégítése körében merülnek föl.

Az ún. dual - use (kettös célú) szerzödések megitélése

A fogyasztó fogalom lényeges eleme az üzleti vagy szakmai tevékenységi körén kívüli célból történő eljárás. A foglalkozás körén kívül eső célból történő szerződéskötést, mint a fogyasztói szerződés egyik alapvető jellemzőjét az EuB a Dietzinger[11] ügyben értelmezte. A szóban forgó ügyben az EuB a 85/577 EGK irányelv személyi hatályát vizsgálta és azt állapította meg, hogy ha a zálogszerződést egy természetes személy foglalkozásán kívül eső célból kötötte, ámde az egy olyan fökötelezett adósságának biztosítékául szolgál, aki a föszerződést foglalkozása körében kötötte, nem fog az irányelv hatálya alá tartozni. Ez továbbá felveti azt a kérdést, hogy ha a szerződés tárgyát igénybe vevő fél azt nemcsak üzleti, hanem magáncélra is használja, megalapozza-e fogyasztói minőségét a szerződésben. Ezeket a szerződéseket nevezi a külföldi jogirodalom dual-use szerződéseknek. A fogyasztóvédelmi irányelvekben és a legtöbb tagállami jogrendszerben nem találunk erre vonatkozó szabályozást. Egyedül a hibás termékekért való felelősségre vonatkozó tagállami törvényi, rendeleti és közigazgatási rendelkezések közelítéséről szóló 85/374/EGK tanácsi irányelv tartalmaz 9. cikkében a „kár” meghatározásakor hasonló megfogalmazást, amely szerint kárnak minősül a hibás terméken kívül más dologban okozott kár, vagy a dolog megsemmisülése 500 ECU értékhatár fölött, feltéve, hogy a dolog (a.) általában személyes használatra vagy fogyasztásra szolgál, és (b.) azt a károsult elsősorban személyes használatára vagy fogyasztásra fordította.

Az EuB az Osztrák Legfelsőbb Bíróság (OHG) kérelmére indult előzetes döntéshozatali eljárásában foglalt állást a dual-use kérdésben az osztrák mezőgazdász Johann Gruber [12]ügyében. $\mathrm{Az} \mathrm{EuB}$ tehát annak a kérdésnek a vizsgálatát rendelte a hazai jogalkalmazók feladatkörébe, ,[...], hogy a kérdéses szerződést el nem hanyagolható mértékben az érintett kereskedelmi vagy szakmai tevékenységéhez sorolható szükségleteinek kielégítésére kötötték, vagy éppen ellenkezöleg, a kereskedelmi vagy szakmai cél szerepe jelentéktelen." Johann Gruber téglát vásárolt a német Bay Wa AG gazdálkodónál, amelyet a udvarának burkolásához kívánt felhasználni. Udvarát 60 \%-ban magán, 40 \%-ban mezőgazdasági tevékenység keretében használta. Azt a kérdést kellett megválaszolnia az EuB-nak, hogy a polgári kereskedelmi ügyekben irányadó bírósági joghatóságról és a bírósági határozatok végrehajtásáról szóló, 1968. szeptember 27-i egyezmény joghatósági szabályainak értelmében fogyasztónak minősül-e Gruber Úr. Az EuB egyértelmüen kimondta, hogy az a személy, aki részben a kereskedelmi vagy szakmai tevékenységéhez tartozó, részben kereskedelmi vagy szakmai tevékenységén kívüli célt szolgáló dologra nézve köt szerződést, nem hivatkozhat ezen egyezmény 13-15. cikkében írt, a fogyasztói szerződésekre vonatkozó különös joghatósági szabályokra, kivéve, ha a kereskedelmi vagy szakmai használat olyannyira mellékes, hogy a kérdéses ügylet teljes összefüggésére figyelemmel teljesen alárendelt szerepet játszik. Az a tény pedig jelentéktelen, hogy a nem kereskedelmi és nem szakmai cél van túlsúlyban.

\subsection{A kereskedő fogalma}

A fogyasztóvédelmi szabályozás sajátja, hogy az alkalmazási köre kifejezett szerződési viszonyokat, szituációkat ölel fel, így a laikus fogyasztóval szemben egy professzionális 
félnek kell állnia. A gazdálkodó megjelölése a fogyasztóvédelmi irányelvekben eltérően alakul, azonban egy közös tulajdonságukat mindenképpen megállapíthatjuk: a gazdálkodó egy jogi vagy természetes személy, aki a szerzödés megkötésekor szakmai vagy üzleti tevékenységi körében jár el. A fogyasztó és a gazdálkodó fogalmai kölcsönhatásban állnak egymással, ugyanis ha az egyik határait kiterjesztjük, a másik határai szükségszerúen visszahúzódnak.

A kereskedö nevében eljáró személy

A közösségi jog a kereskedő fogalmának meghatározásakor néhol kiterjesztő megközelítést alkalmaz. Az üzlethelyiségen kívül kötött szerződések esetén a fogyasztók védelméről szóló tanácsi irányelv (85/577/EGK) 2. cikke nemcsak azt a természetes vagy jogi személyt tekinti kereskedőnek, aki vagy amely a szóban forgó üzletkötés során kereskedelmi vagy szakmai minőségében jár el, hanem minden egyéb olyan személyt, aki a kereskedő helyett és nevében jár el.[13] Az EuB a kereskedő nevében eljáró személy kategóriáját csupán egy ügyben[14] érintette. A Volksbank eG kontra Klaus Conrads, Frank Schulzke és Petra Schulzke-Läsche, Joachim Nitschke C-229/04 ügyben hozott ítélete szerint a 85/577/EGK tanácsi irányelv 1 . és 2 . cikkét úgy kell értelmezni, hogy amennyiben a kereskedő helyett vagy nevében egy harmadik személyt is bevonnak a szerződés letárgyalásának vagy megkötésének folyamatába, az irányelv alkalmazása nem tehető attól függővé, hogy a kereskedő tudott vagy tudnia kellet volna arról, hogy, a szerződést házaló kereskedés keretében kötötték.

\section{Tájékoztatási kötelezettség}

A fogyasztóvédelmi irányelvek szabályozási sajátossága, hogy egy különös védelmet igénylö szituációt nevesítve, a magánjogban megszokott diszpozitivitástól eltérō, kógens minimális tájékoztatási szabályok betartását rendelik a gazdálkodóknak, avagy többletjogosultságokhoz juttatják a fogyasztókat. Ahogyan azt korábban a tájékoztatási szabályozási modellnél részletesen ismertettük a fogyasztók ezen eszközzel való védelmének alapjául az a megfontolás szolgál, hogy a fogyasztó - jóllehet a magánjogi jogviszonyban egyenrangú félként vesz részt a szerződések megkötésében - mégis információ hiányban szenved. Ezt az információs hiányt B2B avagy C2C viszonyrendszerben a nemzeti magánjogok a kötelmi jog alapelveken és a szerződések általános szabályain keresztül orvosolni tudják, viszont egy B2C viszonyrendszerben, ahol a fogyasztó gyengébb pozíciója a jogalkotó által is méltányolt körülmény, ezt az információs aszimmetriát csakis kógens szabályok elöírásával hozhatják egyensúlyba. Annak meghatározása, hogy a fogyasztónak milyen volumenü információ mennyiségre van szüksége ahhoz, hogy szerződéskötési pozíciójában a kereskedőével kiegyenlített legyen, valamint egy megalapozott ügyleti döntést hozhasson bonyolult jogalkotói folyamat eredménye. A fogyasztó kiszolgáltatottsága (szerződéskötéskori pozíciója) függ a mindenkori szerződéskötési szituációtól, a szerződéskötés módjától (üzleten kívül kötött szerződések, távollevők között kötött szerződések, elektronikus kereskedelem), a szerződés tárgyától (pénzügyi szolgáltatás, timeshare, utazási csomag) és persze függ a fogyasztó intellektuális képességeitől. Tekintettel arra, hogy az európai jog nem lehet terepe a végtelen relativizálásnak (tehát, hogy a fogyasztó tájékoztatási szükségét a mindenkori értelmi színvonalához igazítva vizsgálják egyedi ügyenként), így mindenképpen szükséges egy átlagos fogyasztó mintájához, modelljéhez igazítani a tájékoztatási kötelezettségek mértékét. $\mathrm{Az}$ európai jogalkotó az ,átlagosan informált, figyelmes és értelmes átlagfogyasztó” magatartását figyelembe véve határozza meg a fogyasztóvédelmi jogszabályok tájékoztatási standardjait. Ennek ellenére sem találkozhatunk ugyanazzal a tájékoztatási kötelezettséggel mindegyik európai fogyasztóvédelmi jogszabály esetében, ugyanis a szerződés típusa, a szerződés speciális tárgya, vagy éppen a szerződéskötés módja adott esetben más információk megadását teszi szükségessé, továbbá a fogyasztói modell differenciálódásának jelenségével is találkozhatunk, amely az átlagfogyasztótól eltérő fogyasztó információs szükségleteit is 
figyelembe kívánja venni. A tájékoztatási kötelezettséggel kapcsolatban az alábbi kérdések bírnak relevanciával:[15] ad1: A tájékoztatási kötelezettség teljesítésének tartalma és ideje (szerződéskötést megelőző, szerződéskötéskori); ad2 A tájékoztatás formája (módja, nyelve); ad3 A tájékoztatási kötelezettség megsértésének jogkövetkezményei.

\subsection{A tájékoztatás tartalma}

A fogyasztóval szerződő kereskedőt többlet-tájékoztatási kötelezettség terheli, melynek tartalmát a jogszabályok taxatíve módon rögzítik. A kereskedő köteles a jogszabály által meghatározottakról az ott előírt formában és időben a fogyasztót tájékoztatni, de ez nem érinti azt, hogy ettől eltérő körülményekröl is tájékoztatást adjon. A tájékoztatással szemben fennálló általános követelmény, hogy elő kell segítenie a fogyasztó döntését, érthető módon, világos formában kell az információkat rendelkezésre bocsátani, anélkül, hogy az a fogyasztót megtévesztené. A tájékoztatás tartalma tekintetében kijelenthetjük, hogy minden olyan lényeges körülményről tájékoztatni kell a fogyasztót, amelynek tudatában kell lennie az ésszerü ügyleti döntés meghozatalához. A lényegesnek minősítés alapját a mindenkori fogyasztói minta, valamint a szabályozandó szerződés specialitásai jelentik, az európai jogalkotó célja, hogy a felek között fennálló információs aszimmetriát az adott szerződés kapcsán kiegyenlítse. A lényegesnek minősített körülmények több jogszabályban is kifejezésre kerülnek, jóllehet eltérő megközelítésböl. A CRD 5. cikk 1. pont a)-h) alpontjaiban határozza meg a távollevők és üzleten kívüli szerződésektől eltérő szerződések esetén adandó általános tájékoztatási kötelezettség minimumát (áru vagy szolgáltatás lényeges tulajdonságai; teljes ár; kereskedő adatai; szállítási, fizetési, teljesítési feltételek, megfelelőség igazolás, jótállás, kapcsolódó szolgáltatás; szerződés időtartama; digitális tartalommal kapcsolatos specialitások), amely összhangban van a tisztességtelen kereskedelmi gyakorlatokról szóló irányelv[16] 5. cikk (1) bekezdésében foglaltakkal, ahol a jogszabály az ügyleti döntés befolyásolását vagy arra való alkalmasságot (tisztességtelen kereskedelmi gyakorlatot) az ott meghatározott lényeges körülmények tekintetében fennálló megtévesztés esetén ismeri el.

A tájékoztatási kötelezettség kiegészül termék- vagy szerződéstípus-specifikus tájékoztatási elemekkel is. A CRD a távollevők és üzleten kívül kötött szerződések vonatkozásában határozza meg a különös tájékoztatási kötelezettségeket (elállás joga; a távközlő eszköz használatának díja, ha azt az alapdíjtól eltérően állapítják meg; a vállalkozás ajánlati kötöttségének ideje; ügyfélszolgálat adatai). A szervezett utazási formákról szóló irányelv[17] 4. és 5. cikk (1) bekezdése rendelkezik a tájékoztató füzet kötelező tartalmi elemeiről (az úti cél és az utazási eszköz, annak jellemzői és kategóriája; a szállás típusa, elhelyezkedése, kategóriája és főbb jellemzői, étkezési rend; útiterv, útlevél és vízumelöírások stb.), valamint a fogyasztónak nyújtandó kötelező tájékoztatási elemekről (útlevél- és vízumelö́rások, és különösen azok beszerzésének időtartama; az utazással és az otttartózkodással kapcsolatos egészségügyi elöírások; a közbenső megállók és a csatlakozások ideje és helye; a szervező és/vagy a közvetítő helyi képviselöjének neve, címe és telefonszáma, vagy amennyiben ilyen nincs, a helyi ügynökségek adatai, amelyektől a fogyasztó probléma esetén segítséget kérhet; a fogyasztó részéről történő lemondás vagy baleset, illetve betegség esetén a segítségnyújtás, beleértve a hazaszállítást is, költségeinek fedezetét célzó biztosítási kötvény megkötésének lehetőségére vonatkozó információ). A fogyasztói hitelmegállapodásokról szóló 2008/48/EK irányelv például a tájékoztatás követelményeként azt rögzíti, hogy annak érdekében, hogy a fogyasztók a tények teljes ismeretében hozhassanak döntést, a hitelmegállapodás megkötését megelőzően megfelelő tájékoztatást kell kapniuk a hitel feltételeiről, költségeiről és kötelezettségeikről olyan tájékoztató formájában, amelyet a fogyasztók magukkal vihetnek és tanulmányozhatnak, rendelkezik továbbá a THM-ről és egy reprezentatív példán keresztüli bemutatásról (és többek 
között bevezeti a mintatájékoztató sablon ürlapját is mint a fogyasztói tájékoztatás új formáját). A timeshare irányelv a tájékoztatás tartalma tekintetében az irányelv mellékleteként szereplő tájékoztatási formanyomtatványok irányadóak.

\subsection{A tájékoztatás ideje}

A tájékoztatás ideje tekintetében a legtöbb irányelv úgy fogalmaz, hogy a szerződéskötés megelőzően (legkésőbb a s szerződéskötéskor) kell a fogyasztó rendelkezésére bocsátani a kötelező információkat, de arra is van lehetőség, hogy az elmulasztott tájékoztatást később pótolják (ez vonatkozhat a tartalmilag hiányos vagy formailag hibás tájékoztatás korrigálására is). Az időben többszintü tájékoztatási rendszerek kialakítása mellett az az érv szól, hogy a fogyasztónak megfelelő időt kell biztosítani arra, hogy átgondolt és a megfelelö információk birtokában tudatos ügyleti döntést hozzon, valamint el kell kerülni azt a helyzetet, hogy a szerződéskötés pillanatában (az azt közvetlenül megelőző tárgyalások alkalmával) zúdítsák a fogyasztóra az információhalmazt. A CRD kizárólag a szerződést megelőző tájékoztatás rendszerét szabályozza oly módon, hogy a szerződés érvényességét teszi ettől függővé (tehát a tájékoztatás nem korrigálható később). A szervezett utazásokról szóló irányelv a tájékoztatás időbelisége tekintetében szabályozza a tájékoztató füzet (a szerződéskötés megelőző tájékoztatási forma, azonban még nem feltétlenül a szerződést megelőző tárgyalások része) tartalmát, külön rendelkezik a szerződéskötést megelőző információkról, valamint az utazás kezdetét megelőzően megfelelő időben tett tájékoztatás tartalmáról. A timeshare irányelv szintén a szerződést kellő időben megelöző tájékoztatásról ír (tudatos és átgondolt ügyleti döntés meghozatalához szükséges időt hagyva a szerződéskötés elött), azzal hogy a tájékoztatás később is korrigálható. A fogyasztói hitelmegállapodásokról szóló irányelv többrétegü tájékoztatási rendszert épít ki, a szerződést megelőző, a szerződéskötéskori és a szerződéskötést követő tájékoztatásról rendelkezik (meghatározva azok kötelező tartalmi elemeit).

\subsection{Világos és egyértelmü tájékoztatás követelménye}

A 93/13/EGK irányelv 5. cikke rendelkezett az írásban lefektetett feltételekröl, amelyekkel kapcsolatban a világosság és érthetőség követelményét rögzítette, amit a nemzeti jogalkotók csak nehézkesen voltak hajlandóak implementálni (hiszen szankció nem füződött a megsértéséhez), pontosan amiatt, mert ez a követelmény nehezen tölthető meg tartalommal. Ugyanezen irányelv preambulum bekezdésében rögzíti, hogy „,[...] a szerződéseket egyszerü, érthető nyelven kell megfogalmazni." Az egyértelmüség és közérthetőség követelménye immáron explicit módon jelenik meg a fogyasztói jogokról szóló irányelvben, amely már a közös tájékoztatási szabályok kijelölésének igényével lépett fel. A szervezett utazási formákról szóló irányelv a tájékoztatás módja tekintetében a szerződés megkötését és az utazás kezdetét megelőző tájékoztatást írásban vagy egyéb megfelelő módon rendeli teljesíteni[18] (a tájékoztató füzet egyértelműen írásbeli vagy elektronikus formát feltételez). A 98/6/EK irányelv 4. cikke az eladási ár és az egységár feltüntetésével kapcsolatban az egyértelmüség, a könnyü beazonosíthatóság és a tisztán olvashatóság követelményét jelöli meg. A timeshare irányelv alapján (4. cikk) világos és érthető módon pontos és elégséges tájékoztatást kell a kereskedőnek nyújtani tájékoztatási formanyomtatványok használatával. Ezen irányelv további követelményként rögzíti (5. cikk), hogy „,...] a szerződést írásban, papíron vagy más tartós adathordozón" bocsássák rendelkezésre, és a fogyasztó választása szerint a lakóhelye vagy állampolgársága szerinti tagállam nyelvén való megszövegezést kérheti, feltéve hogy az adott nyelv a Közösség hivatalos nyelve. A fogyasztónak ezeken felül a szerződésből egy példányt kézhez kell kapnia.” A fogyasztói hitelmegállapodásokról szóló irányelv alapján az információkat nyomtatott formában vagy más tartós adathordozón, az 
irányelv II. mellékletében foglalt „Általános európai fogyasztói hiteltájékoztató” címü formanyomtatvány felhasználásával kell a fogyasztó rendelkezésére bocsátani.

\subsection{A tájékoztatás megsértésének jogkövetkezménye}

Több megoldás létezik a fogyasztóvédelmi jogban, mivel új generációs fogyasztóvédelmi jogszabályokról van szó, nehezen mondhatnám ki bármelyikről, hogy a main stream-et képviselné. Az új timeshare irányelv[19] a tájékoztatás elmaradásának következményeként az elállási idő meghosszabbításáról rendelkezett (ha ez elállási jogról szóló tájékoztatás akár tartalmában akár formájában nem felel meg, akkor 1 év 14 nappal hosszabbodik meg az elállás, ha a kötelező tájékoztatás egyéb elemeiröl sem formailag sem tartalmilag nem megfelelö a fogyasztók tájékoztatás, akkor 3 hónap 14 nappal hosszabbodik meg), a fogyasztói hitelmegállapodásokról szóló irányelv egyszerüen az elállásra rendelkezésre álló idő kezdetét tette arra az időpontra, amikor a kereskedő teljesíti a szerződést megelőző tájékoztatási kötelezettségeit. Ezzel szemben a CRD új szabályozása meröben más elképzeléseket követ, ugyanis a kereskedő szerződés megkötését megelőző kötelességeinek elmulasztása (nem egyértelmű és érthető módon való közlése) esetén a szerződés, vagy az ajánlat nem köti majd a fogyasztót, és mivel az irányelv 6. cikkének (5) bekezdése alapján az említett tájékoztatás a távollevők között vagy az üzlethelyiségen kívül kötött szerződés szerves részét képezi, így ezek nélkül egyébként - a várható joghatásokat tekintve - a szerződés érvényesen létre sem jöhet.

\section{Elállás joga}

Az európai jogalkotó által fogyasztóknak juttatott többletjogosultság az elállási jog. Az elállási jog a szerződés joghatásaiba történő beavatkozásként is értékelhető, méghozzá olyan okból, amelyet a hagyományos mellérendelt jogviszonyokban a jogalkotó nem ruház fel relevanciával, és nem rendel hozzá jogosultságokat illetve jogkövetkezményeket. A fogyasztó ugyanis hajlamos gyorsan, meggondolatlanul dönteni, így a szerződés megkötését követően szüksége van egy ún. kijózanodási időszakra (cooling off period), hogy hidegebb fejjel újraértékelhesse ügyleti döntését. Természetesen az európai jogalkotó sem minden fogyasztói szerződés esetében juttatja ezt a többletjogosultságot a jogosultnak, hanem csakis a túlzottan egyensúlyhiányos szerződéskötési szituációkhoz rendeli. Túlzottan egyensúlyhiányos helyzet létrejöhet a szerződéskötési szituáció jellegéből adódóan (távollevők között- és üzleten kívül kötött szerződések)[20], valamint a kínált termék specialitásai miatt is (fogyasztói hitel, timeshare). Az európai fogyasztói szerződésekben szabályozott elállási jog közös jellemzője, hogy az nem kötődik a kereskedő szerződésszegéséhez (nem szankciós jellegü), a fogyasztó indokolás nélkül gyakorolhatja ezt a jogát bármikor az elállásra nyitva álló határidő végéig.[21] Az elállási határidő kezdete és vége tekintetében többféle megoldás létezik: egyrészt az irányelvek a tájékoztatási kötelezettség nem elöírt teljesítésének szankcionálásaként az elállási határidő meghosszabbodását rendelik objektív határidőként, valamint a tájékoztatás időközbeni teljesítéséhez kötik az elállásra nyitva álló idő kezdetét. Az elállás egyébként a termék kézhezvételével, a szolgáltatás nyújtása esetén rendszerint a szerződés megkötésének napjával vagy a szerződés kézhezvételével kezdődik.[22]

Az elállás gyakorlásának módja tekintetében egységesek az irányelvek abban, hogy az elállásnak igazolható módon, a gazdálkodó vagy a jogszabály által meghatározott rend szerint kell történnie. A legújabb generációs irányelvek (timeshare, CRD) elállási formanyomtatványt rendszeresítettek erre az esetre, de bármilyen más egyoldalú nyilatkozatot is elfogadnak a fogyasztó részéről. A fogyasztói hitelmegállapodásokról szóló irányelv az elállás gyakorlásával kapcsolatban igazolhatóságot ír elő, követve a korábbi irányelvek megfogalmazását. Egy példával szemléltetve a megfelelő időben és módon történő elállást: a határidőt betartottnak kell tekinteni, ha az értesítést nyomtatott formában vagy más, a hitelező 
számára elérhető és hozzáférhető tartós adathordozón a határidő lejárta elött feladják [14. cikk (3) bek. a) pont]. Közös jellemző továbbá, hogy a felek minden esetben meghatározott időn belül az eredeti állapot helyreállítására kötelesek, az ezzel kapcsolatos költségeket azok felmerülésétől függően viselik, továbbá megszünnek a szerződés teljesítéséhez füződő kötelezettségeik. A fogyasztó ezen felül nem tartozik kártérítéssel, kártalanítással. A CRD szakított azzal a korábbi gyakorlattal, amely szerint a fogyasztó az elállásra nyitva álló határidő alatt a termék rendeltetésszerü használatából eredő értékcsökkenést nem volt köteles megtéríteni[23] (csak a rendeltetésellenes használatból eredö értékcsökkenést), jelenleg a fogyasztó az áruk jellegének, tulajdonságainak és müködésének megállapításához szükséges kezelésből adódó értékcsökkenést meghaladó értékcsökkenésért felel [14. cikk (2) bek.].

\section{A jogszabályi tartalomtól való eltérés korlátozása, egyoldalú kógencia}

A fogyasztóvédelmi jogszabályok kógens szabályokat tartalmaznak, amelyeknek kötelező jellege két dimenzióban is érvényesül: ad1 A nemzeti jogalkotó irányába a minimum harmonizálandó irányelvek esetében egyedül a fogyasztó érdekében lehetett eltérni (szigorúbb szabályokat bevezetni vagy fenntartani), vagy a maximum harmonizálandó irányelvek esetében eltérésre nem volt lehetőség; ad2: A szerződéses jogviszonyban a fogyasztóvédelmi jogszabályok a szerződések tartalmi elemeit, formáit eltérést nem engedő, vagy csak a fogyasztó érdekében eltérést engedő módon szabályozzák. Alapszabályként érvényesül tehát, hogy a fogyasztó hátrányára ezektől eltérni nem lehet. Ennek pozitív megfogalmazása a fogyasztói jogokról szóló irányelv 3. cikk (6) bek., amely alapján az irányelv ,,[...] nem akadályozza a kereskedőket abban, hogy a fogyasztóknak olyan szerződéses megállapodásokat ajánljanak, amelyek az ebben az irányelvben nyújtottnál nagyobb védelmet biztosítanak."

\section{A joglemondás tilalma}

A fogyasztóvédelmi szabályozás másik sajátossága, hogy a fogyasztó az európai jogszabályok által számára biztosított jogokról érvényesen nem mondhat le. Ezt a felek szerződési szabadsága alapján érvényesülő tartalmi és formai szabadság sem ronthatja le, nem lehet érvényes az olyan szerződési feltétel sem, amely lemondatja a fogyasztót ezen jogairól (pl.: CRD 25. cikk: „,...] a fogyasztó nem mondhat le azokról a jogairól, amelyeket az ezen irányelvet átültető nemzeti intézkedések biztosítanak számára. Azok a szerződési feltételek, amelyek szerint a fogyasztó közvetlenül vagy közvetve lemond az ezen irányelvböl eredő jogokról, illetve elfogadja azok korlátozását, nem kötelezők a fogyasztóra nézve.”)

\section{A jog- és fórumválasztás korlátozása}

A fogyasztók védelmének elve nemcsak a hagyományos anyagi jogok keretein belül valósítható meg, hanem a kollíziós jogszabályok is védelemben részesíthetik a fogyasztók meghatározott körét. A kollíziós jogszabályok alkalmazási területei pontosan azok a határon átnyúló jogviszonyok, amelyek térhódítását az európai jogalkotó is ösztönözni szeretné. Figyelembe véve azt a tényt, hogy az európai nemzetállamok fogyasztóvédelmi joganyaga csupán egy minimális szinten harmonizált, az EU-n kívüli országok joga talán ilyen mértékben sem részesíti védelemben a fogyasztói társadalmat, akkor kijelenthetjük, hogy a kollíziós kötelmi jog alappillérének számító jogválasztás intézményének korlátlan gyakorlása ismét a fogyasztók kihasználásához vezethet. Egy a fogyasztóétól eltérő ország jogának választása hátrányosabb helyzetbe hozhatja a fogyasztót, mint a vele szemben álló kereskedőt, tekintettel az egyedileg meg nem tárgyalt szerződési formákra. Ebből adódóan a szerződéses kötelezettségekre alkalmazandó jogról szóló Róma I. rendelet a fogyasztói szerződésekre 
speciális szabályokat alkotott, amelynek értelmében a fogyasztót nem lehet jogválasztással megfosztani a szokásos tartózkodási helye szerinti ország jogának fogyasztót védő rendelkezéseitől. Ennek az a feltétele, hogy a gazdálkodó tevékenységét, amellyel kapcsolatban a szerződés megkötésre került, a fogyasztó szokásos tartózkodási helye szerinti országban végezze, vagy ebbe az országba irányuljon. A fórumválasztás kapcsán a fogyasztó szintén méltánylást érdemlő helyzetben van, a polgári és kereskedelmi ügyekben a joghatóságról, valamint a határozatok elismeréséröl és végrehajtásáról szóló Tanács 44/2001/EK rendelet (Brüsszel I. rendelet) 15-17. §-ai alapján a fogyasztó saját lakóhelye vagy székhelye (a Brüsszel I. alapján nemcsak természetes személy minősülhet fogyasztónak) szerinti bíróság előtt indíthat pert és perelhető. E jogáról csak korlátozásokkal mondhat le.[24]

Összegzésként megállapítható, hogy a szerződéses szituációk igen színes palettáját felvonultató fogyasztói szerződések jogában fellelhetőek ugyanazon hatásmechanizmusú jogintézmények, amelyek mentén a fogyasztói szerződések szabályozásának közös magja elkülöníthető és megalkotható. Nyilvánvaló ugyanakkor, hogy a szerződés tárgyából, vagy a szerződéskötés módjából adódó specialitások jóllehet igénylik ugyanazon többletjogosultság meglétét (pl elállási jog), de bizonyos esetekben egy hosszabb elállási idő egyáltalán nem indokolt. Végezetül úgy vélem, hogy az európai jogalkotó a fogyasztói jogokról szóló irányelv megalkotásakor mindezeket megfelelően mérlegelte, tényleges kísérletet tett a fogyasztói szerződések általános tájékoztatási standardjainak megalkotására és a távollevők közötti és üzleten kívüli kötelmek jogában pedig valódi jogegységesítést valósít meg.

Hajnal Zsolt publikációt megalapozó kutatása a TÁMOP 4.2.4.A/2-11-1-2012-0001 azonosító számú Nemzeti Kiválóság Program - Hazai hallgatói, illetve kutatói személyi támogatást biztosító rendszer kidolgozása és müködtetése országos program címü kiemelt projekt keretében zajlott. A projekt az Európai Unió támogatásával, az Európai Szociális Alap társfinanszírozásával valósul meg.

\section{Europäisches Verbrauchervertragsrecht: gemeinsame Fundamente - Zusammenfassung}

Der Verbraucherschutz korrigiert durch die rechtliche Regelung, durch Ausbau eines interdisziplinieren Rechtsinstrumentsystems versichert es Rechtsschutz für die Verbraucher in schwächerer Position. Durch rechtlichen Instrumenten wird die optimale Gleichgewichtslage wiederherstellt, demnoch werden die optimalen Verhältnisse geschafft, unter denen die Verbraucher freie Kaufsentscheidungen treffen können und nach eigenen Bedürfnissen „konsumieren” können. Die modernen Rechtsysteme haben als eigenes das ideale Leitbild des Schutzes der schwächeren Partei, diesbezüglich der Schutz vom hohen Niveau der Verbraucherinteressen kann als dritte Generation der Menschenrechte begriffen werden. Also der Verbraucherschutz wurde inzwischen die Sicherung für Lebensniveau der Europabürger und dient neulich auch als Mittel erneuerter Impulze für europäische Wirtschaft zu geben.

Ziel dieses Artikels ist zu untersuchen, ob irgendwelche Harmonisierung in Rahmen einer Rahmenrichtlinie oder Vereinheitlichung der Verbraucherrechte in Europa eigentlich verwirklich werden könnte. Vor den Feststellungen der endgültigen Konklusionen müssen wir genau anschauen ob die europäischen Verbraucherregelungen gemeinsame Wurzeln oder gemensame Instrumente verfügen. Diesmal dient es als Kerngebiet meiner Forschung. 
*PhD, egyetemi adjunktus, DE ÁJK.

[1]Az európai magánjogegységesítéshez bővebben: Az európai fogyasztóvédelmi jog kialakulásához lásd bővebben: Fazekas Judit, Fogyasztóvédelmi Jog, Complex Budapest (2007) 19-36., Fézer Tamás, Eredmények és lehetőségek az egységes európai magánjog kialakításának folyamatában, Collectio Iuridica Universitatis Debreceniensis V., Debrecen (2005); Hajnal Zsolt: 169. cikk, in: Az Európai Unióról és az Európai Unió müködéséről szóló szerződések magyarázata 1-3. - Kommentár (szerk.: Osztovits András) Complex, Budapest (2011) 2419-2433., Hámori Antal: A közösségi fogyasztóvédelmi politika és jog fejlődése, in Agora (2008) (2) 39-54., Szikora Veronika: A fogyasztóvédelmi jog történeti kialakulása Európában, különös tekintettel a magánjog-egységesítési folyamatokra, in: Magyar fogyasztóvédelmi magánjog - európai kitekintéssel (szerk.: Szikora Veronika), (A Fogyasztóvédők Magyarországi Egyesületének kiadványa), Center Print Nyomda, Debrecen (2010) 19-30., Osztovits András: Európai fogyasztóvédelmi magánjog, in: Európai fogyasztóvédelmi magánjog. (szerk.: Osztovits András) HVG-Orac, Budapest (2006) 15-48., Reich, Norbert: Verbraucherpolitik und Verbraucherschutz im Vertrag von Amsterdam, (1999) Verbraucher und Recht, 4., Bourgoignie, Thierry: European Community consumer law and policy: from Rome to Amsterdam, Consumer Law Journal 1998., 443-462, Micklitz Weatherill: Consumer Policy in the European Community: Before and After Maastricht, Journal of Consumer Policy (1993) 285-321., Vékás Lajos: Európai közösségi fogyasztóvédelmi magánjog, in: Európai közösségi jogi elemek a magán- és a kereskedelmi jogban (szerk.: Vékás Lajos), KJK-KERSZÖV, Budapest (2001) 25-96., Király Miklós: Az Európai Közösség kereskedelmi joga, KJK, Budapest (1998), Török Éva: Az európai szerződési jog fejlődésének tendenciái, Debreceni Jogi Mühely, 2011/4. (8. évf.); Zoványi Nikolett: A fogyasztóvédelem történeti fejlődése és szabályozási elvei, Debreceni Jogi Mühely, VIII. évfolyam 3. szám (www.debrecenijogimuhely.hu)

[2]Schulte-Nölke - Twigg-Flesner - Ebers: EC Consumer Law Compendium, Sellier, München (2008) 1- 529.

[3]C-220/98 Estée Lauder Cosmetics GmbH \& Co. OHG v Lancaster Group GmbH[2000] EBHT I-117 219.; C-479/93 számú jogeset,. Verein gegen Unwesen im Handel und Gewerbe Köln e. v. / Mars GmbH (1995) I-1923.

[4]A fogyasztó fogalmáról lásd: Hámori Antal: A „fogyasztó”-fogalom „dilemmái” különös tekintettel az Fgytv. módosításában és az új Ptk.-javaslatban foglaltakra, Magyar Jog, 2009/2. 89., Meskic (2008) 51., Fazekas Judit: Fogyasztóvédelmi jog Complex, Budapest 2007. 80., Miskolczi Bodnár Péter - Sándor István: A fogyasztóvédelmi jog magyar szabályai, Petrocinium Kiadó (2010) 32-37., Lurger, Brigitta - Augenhofer, Susanne: Österreichisches und Europaeisches Konsumentenschutzrecht, Springer Wien, New York (2008) 34-44., Vékás Lajos: Az Európai közösségi magánjog sajátos alanyáról: a „fogyasztó” fogalmáról, Európai Jog, 2002/5. 3-13.

[5]A fogyasztói hitelmegállapodásokról szóló 2008/48/EK számú Európai Parlament és a Tanács irányelv 3. cikk a) pontja szerint a fogyasztó olyan természetes személy, aki az ezen irányelv hatálya alá tartozó ügyletek keretében olyan célból jár el, amely kívül esik szakmája, üzleti tevékenysége vagy foglalkozása körén.

[6]A 90/314/EGK irányelv 2. cikk 4. pontja: fogyasztó: az a személy, aki igénybe veszi vagy megállapodást köt arról, hogy igénybe fogja venni a szervezett utazási formát (,a megbízó fél”), vagy olyan személy, akinek a nevében a megbízó fél megállapodást köt a szervezett utazási forma megvásárlásáról (,a többi kedvezményezett”), vagy olyan személy, akire a megbízó fél vagy a többi kedvezményezett egyike a szervezett utazási formát átruházza (,az engedményes").

[7]A fogyasztó kollíziós jogban foglalt fogalmához bővebben Loacker, Leander D. Der Verbrauchervertrag im internationalen Privatrecht. Zum Anwendungsbereich von Artikel 5 
des Europäischen Schuldvertragsüberkommens aus österreichischer und deutscher Sicht., Sellier.European Law Publishers, München (2006) 54-65.

[8]HL L 012, 16/01/2001. 1 - 23., 15. cikk (1) bek.

[9]C-541/99. sz. és C-542/99. sz. egyesített ügyek 2001.11.22., EBHT 2001 I-09049.

[10]C-361/89., EBHT 1991, I-1189.

[11]A Bíróság 1998. március 17.-i ítélete a Bayerische Hypotheken- und Wechselbank AG kontra Edgard Dietzinger, C-45/96. sz. ügyben, EBHT 1998 I-01199

[12]C-464/01; EBHT 2005, I-439.

[13]Hasonló megfogalmazást tartalmaz még a a belső piacon az üzleti vállalkozások fogyasztókkal szemben folytatott tisztességtelen kereskedelmi gyakorlatairól szóló 2005/29/EK Európai Parlament és a Tanács irányelv is.

[14]Volksbank eG kontra Klaus Conrads, Frank Schulzke és Petra Schulzke-Läsche, Joachim Nitschke C- 229/04 sz. ügy (1995. 10. 25.) EBHT I-9293.

[15]Fazekas (2007) 138-139.

[16]Az Európai Parlament és a Tanács 2005/29/EK irányelve (2005. május 11.) a belső piacon az üzleti vállalkozások fogyasztókkal szemben folytatott tisztességtelen kereskedelmi gyakorlatairól, valamint a 84/450/EGK tanácsi irányelv, a 97/7/EK, a 98/27/EK és a 2002/65/EK európai parlamenti és tanácsi irányelvek, valamint a 2006/2004/EK európai parlamenti és tanácsi rendelet módosításáról („Irányelv a tisztességtelen kereskedelmi gyakorlatokról") (HL L 149., 2005.6.11. 22-39.)

[17]A Tanács 1990. június 13-i 90/314/EGK irányelve a szervezett utazási formákról (HL L 158., 1990.06.23. 59-64.)

[18]A Tanács 1990. június 13-i 90/314/EGK irányelve a szervezett utazási formákról (HL L 158., 1990.06.23. 59-64.) Preambulum: [...] mivel ez megfelelően megvalósítható, ha a szerződés minden feltételét írásban rögzítik egy olyan okmányban, amely számára (fogyasztó) érthető és hozzáférhető, és amelynek egyik példányát kézhez kapja.

[19]Az Európai Parlament és a Tanács 2008/122/EK irányelve (2009. január 14.) a szálláshelyek időben megosztott használati jogára, a hosszútávra szóló üdülési termékekre, ezek viszontértékesítésére és cseréjére vonatkozó szerződések egyes szempontjai tekintetében a fogyasztók védelméről EGT- vonatkozású szöveg (HL L 033, 03/02/2009 0010 - 0030).

[20]Az atipikus szerződésekhez és az elállás jogához bővebben: Papp Tekla: Atipikus jelenségek szerződési jogunkban/ Atypical Phenomena in our Contract Law (magyar és angol nyelvü), Lectum Kiadó, Szeged (2009); Jenovai Petra - Papp Tekla - Strihó Krisztina Szeghő Ágnes: Atipikus szerződések, Lectum Kiadó, Szeged (2011), Csécsy - Fézer - Hajnal - Károlyi - Petkó - Törö (2012) 179-181.

[21]Fazekas (2007) 139-140.

[22]Részletesebben lásd: Csécsy Andrea: A szerződésszegés jogkövetkezményeinek összehasonlító jogi elemzése, PhD értekezés, Miskolci Egyetem, Deák Ferenc Doktori Iskola, Miskolc (2008) 208-213.

[23]A fogyasztók gyakran visszaéltek ezzel a lehetőséggel, 8 munkanapig használták a terméket, majd a 8. munkanapon elálltak a szerződéstől.

[24]A joghatósági rendeletről bővebben: Nagy Csongor István: Az Európai Unió nemzetközi magánjoga. Határon átnyúló jogviták az EU-ban, HvgOrac, Budapest (2006); Wopera Zsuzsa - Wallacher Lajos (szerk.): Polgári eljárásjogi szabályok az Európai Unió jogában. Kommentár a polgári ügyekben való igazságügyi együttműködés keretében elfogadott közösségi normákhoz, Complex, Budapest (2006) 